\title{
Estrategia e inserción del Partido Comunista Revolucionario en el SMATA (1979-1985)
}

\author{
Matias J. Rubio \\ Universidad Nacional de Luján \\ rubiomatias08@hotmail.com.ar
}

En este trabajo abordaremos el papel desempeñado por el Partido Comunista Revolucionario (PCR) ${ }^{1}$ en el Sindicato de Mecánicos y Afines del Transporte Automotor (SMATA)durante el proceso de normalización sindical (1979-1985). ${ }^{2}$ Nuestro principal objetivo es analizar cómo, en esta experiencia concreta, un partido de izquierda logró insertarse en un colectivo de trabajadores y dirigir uno de sus sectores. Con ello apuntamos a relevar, comprender y dimensionar las prácticas e ideas en juego en tal accionar. Esto nos permitirá reflexionar sobre un tema clave en la historia de los movimientos sociales: cómo se articula la acción de una clase social con las organizaciones politicas. En nuestra hipótesis

1. Este partido se conformó en 1968 como consecuencia de una ruptura del Partido Comunista (PC). Durante los primeros años de la década de 1970, luego de una inicial simpatía por la experiencia cubana, el PCR fue adoptando el maoísmo como identidad politica hasta asumirlo orgánicamente en su III congreso partidario (1974). A diferencia de otros partidos que surgieron en la época, rechazó la lucha armada como método de acción política. Su concepción de la revolución en Argentina se vertebró a partir de considerar la necesidad de un paso previo a la revolución socialista: la revolución "democrática, agraria y antiimperialista en camino ininterrumpido al socialismo". Con ella se impuso la condición de una alianza del proletariado urbano y rural con sectores de la "burguesía patriótica" (Partido Comunista Revolucionario, 2007).

2. Tanto la fábrica de Ford ubicada en Gral. Pacheco como el PCR han sido abordados por la historiografia desde distintas perspectivas. En cuanto al establecimiento, contamos con una serie de trabajos que nos proporcionan un panorama general del desenvolvimiento de la política patronal y de la acción de sus trabajadores entre los años previos a la dictadura y el alfonsinismo (Lascano Warner, 2012; Basualdo, 2006; Molinaro, 2013; Bitrán y Schneider, 1992; Abdala, 2015; Hernández, 1985; García Allegrone, Partenio y Fernández Álvarez, 2003; Giniger, Guevara, Hernández y Rivero, 2010). Respecto al partido existen investigaciones que indagaron en la acción y estrategia desenvuelta por la organización de cara al movimiento obrero en el período previo a la dictadura (Laufer, 2015a y 2015b; Lissandrelo, 2014).

(Archivos, año VI, $\mathrm{n}^{\circ} 11$, septiembre de 2017, pp. 143-162) 
de trabajo sostenemos que, por sus prácticas e ideas, el PCR tuvo la capacidad de aglutinar a un conjunto de activistas, a quienes dotó de una impronta antiburocrática, que desempeñaria un rol fundamental en las luchas del periodo.

En este artículo analizaremos las estrategias que el PCR desarrolló en pos de conquistar la dirección sindical y política de los trabajadores mecánicos. En consecuencia, prestamos particular atención a la importancia que adquirió, en determinados momentos, este partido como agrupamiento de vanguardia en el desarrollo de las luchas de los trabajadores. ${ }^{3}$

Comenzaremos planteando el marco general del proceso de normalización sindical y la estrategia del partido, que será el centro de nuestro análisis. Luego abordaremos la dinámica de las disputas al interior del gremio mecánico a partir de dos momentos: los conflictos de base que se dieron entre 1982-1983 y las elecciones gremiales de octubre de 1984. Por último, nos valdremos de la experiencia de Ford Motors Pacheco como la manifestación más cabal de la inserción del PCR en el gremio durante este período. Utilizaremos, para ello, fuentes escritas (publicaciones periódicas, revistas partidarias, boletines y volantes) y orales (entrevistas a partícipes del proceso). ${ }^{4}$

\section{Normalización y dirigencia sindical en SMATA}

Durante el gobierno de facto tuvo lugar una crisis en la industria automotriz que provocó el cierre y retiro del país de algunas empresas, como Chevrolet, Chrysler y Citröen, y llevó a la quiebra a muchas autopartistas. Esto generó, junto con la baja de la producción, ${ }^{5}$ la reducción a un tercio de los trabajadores empleados en la rama con respecto a 1975. La dirigencia del SMATA, José Rodríguez y su Lista Verde, reaccionaron

3. Entendemos vanguardia en el sentido que lo hizo Lenin (2004) en ¿Qué Hacer? (1902). Es decir, como un agrupamiento novedoso que escapa de la tendencia dominante y que podría sentar las bases de un desarrollo futuro distinto. En este sentido, la vanguardia obrera es el segmento de la clase que se distingue de la masa en que, ni aun en un período de calma, abandona el frente de la lucha de clases. De esta manera, opone al espontaneísmo de las masas -que es necesariamente discontinuo- la continuidad de un grupo que procesa las experiencias y enriquece su línea de acción (Mandel, 1972).

4. Mantendremos en el anonimato a los entrevistados y nos referiremos a ellos por su nombre de pila y el rol que ocuparon en aquel contexto.

5. Según los anuarios de la Asociación de Fábricas de Automotores (1986), luego de ser 1985 uno de los años más recesivos para el sector, en 1986 se recuperó la producción (con 165.575 automóviles). Sin embargo, esta mejoria estaba lejos de alcanzar los números previos al golpe de estado: en 1973 se habian producido 285.300 unidades. 
con paros nacionales ante la presión de las bases. Esto llevó a la militarización de algunas fábricas y a la clausura de cualquier representación gremial hasta 1979 cuando comenzó el reordenamiento (Pozzi, 2008).

Al interior del gremio mecánico, durante la dictadura, había una serie de agrupamientos que pujaron por una reorganización que los tuviera como protagonistas. Ellos eran el Movimiento Nacional de Unidad Automotriz - Lista Verde, que controlaba las seccionales de Capital Federal y Gran Buenos Aires; la agrupación Lealtad a Kloosterman, conducida por Rubén Cardozo (que dirigia la seccional de Santa $\mathrm{Fe}$ ), Elpidio Torres, fuerte en Córdoba, y Delfino Pérez, que lideraba algunas plantas de Buenos Aires; y, finalmente, la Lista 22 de Mayo, que controlaba la seccional San Juan. Fueron ellos quienes conformaron una comisión normalizadora que puso fin a la intervención militar en 1983 (Molinaro, 2015).

En aquel momento, la CGT se encontraba dividida en dos grandes alas. Por un lado, estaba la CGT-Azopardo, conformada por el grupo Gestión y Trabajo y la Comisión de los 20, donde participaron los dirigentes mecánicos opositores a Rodríguez. Por el otro, la CGT-Brasil, compuesta por las 62 Organizaciones, lideradas por el metalúrgico y representante del sector ortodoxo del sindicalismo peronista, Lorenzo Miguel, y la Comisión Nacional de los 25, a la cual pertenecía la Lista Verde, que recuperó la conducción del SMATA en 1984. Mientras la primera se mostró más afín a negociar con el Estado, primero con los militares y luego con el alfonsinismo, la segunda llevó a la práctica posiciones más confrontativas, aunque siempre con matices (Belardinelli, 1994). ${ }^{6}$

Según Pablo Pozzi (2008), en 1981, mientras José Rodríguez tenía el respaldo de 19 seccionales, el sector de Cardozo-Torres contaba con 33 seccionales que lo apoyaban. La Lista Verde, en este período, realizó una campaña denunciando que sus opositores contaron con el apoyo del Ministerio de Trabajo y sectores del ejército. ${ }^{7}$

En junio de 1983, el gobierno devolvió la conducción del SMATA a sus antiguas autoridades. La Comisión Normalizadora constó de 28 cargos que se repartieron de la siguiente manera: la Lista Verde contó con 15,

6. La Lista Verde del gremio mecánico, por ejemplo, tuvo posiciones más "combativas" contra el gobierno militar que frente al alfonsinismo. Este último le garantizó la legalidad y el aparato para las elecciones generales del gremio en 1984. Entrevista a Juan, directivo del SMATA (2016).

7. Más allá de que ambos agrupamientos surgen de un tronco común, la principal diferencia se da en la predisposición a negociar con el gobierno militar de Roberto Viola (1981-1982). Mientras el sector conducido por Cardozo ve con simpatía el llamado del presidente a negociar y se apoya en éste para normalizar el sindicato a su favor, la Verde denuncia complicidad y toma una actitud más confrontativa respecto al gobierno. Entrevista a Juan, directivo del SMATA (2016). 
Lealtad a Kloosterman con 7 y la 22 de Mayo con 6 . Estos serán los encargados de volver a poner en funcionamiento el aparato administrativo del gremio y quienes convocaron a las elecciones de octubre de 1984 (Molinaro, 2015). Todo esto transcurrió en el contexto de la derrota de la ley Mucci ${ }^{8}$ y una creciente conflictividad en los lugares de trabajo a partir de la Guerra de Malvinas.

En cuanto a la izquierda, ${ }^{9}$ es necesario distinguir dos momentos de su intervención: un primer periodo en 1982-1983 cuando surgieron delegados, o tomaron visibilidad activistas combativos, y, luego, un segundo momento en el que se conformaron o institucionalizaron las organizaciones de base y la izquierda logró inserción.

\section{La politica del Partido Comunista Revolucionario}

El partido maoísta en cuestión tuvo una experiencia clave en su intervención en el movimiento obrero organizado: la del SMATA-Córdoba. A partir del Cordobazo, el desarrollo del clasismo y la Lista Marrón ${ }^{10}$ determinó una agitación sistemática sobre el proletariado mecánico. Su tercer congreso (1974) fijó como un foco de labor partidario los grandes centros de concentración industrial.

El partido venía de oponerse al golpe de estado de 1976, llamando a los peronistas a defender a Isabel Perón bajo el lema "Otro 55 no pasará". El clima represivo y la ilegalización de la organización lo llevaron a sostener alianzas en la base, en los lugares de trabajo, con muchos sectores del peronismo, fundamentalmente con las 62 Organizaciones. A fines de 1982, el PCR lanzó el Partido del Trabajo y el Pueblo (PTP) como

8. La ley fue presentada ante el Congreso por el Ministro de Trabajo y Seguridad Social de Alfonsín, Antonio Mucci, en 1984. Esta consistía básicamente en comenzar las elecciones sindicales desde abajo (delegados y Comisiones Internas) y luego llevar a cabo elecciones en las entidades gremiales de segundo y tercer grado. El proceso, realizado bajo supervisión de la Justicia Nacional Electoral, comenzaba cuando el Ministerio de Trabajo nombraba una Comisión Transitoria para la convocatoria a elecciones. El proyecto preveía la eliminación del requisito de la antigüedad para presentarse como candidato y otorgaba representación gremial a la minoría que obtuviera el $25 \%$ de los votos o más (Zorzoli, 2016).

9. Las organizaciones de izquierda que tenían inserción en el gremio mecánico eran el Movimiento al Socialismo (MAS), el Partido Comunista (PC), el PCR y el Partido Obrero (PO).

10. La lista Marrón fue un frente electoral de agrupaciones de izquierda, dirigida por el PCR, cuyo objetivo era disputar las elecciones mecánicas en 1972. Esta lista logró conquistar la dirección del gremio provincial y proyectarse como un gran polo de atracción de los sectores clasistas (Laufer, 2015a). René Salamanca, quien fuera secretario general del gremio cordobés desde 1972 hasta su intervención en 1974 y dirigente del PCR, es presentado como el paladín de la política partidaria en el sindicalismo. 
su brazo legal y electoral. En las elecciones de 1983 llamó a votar por el peronismo bajo el lema "Contra la dictadura, votar al peronismo". La creación del PTP abrió un frente de trabajo político de carácter de masas $^{11}$ que marcaba un quiebre con la estrategia clandestina desarrollada previamente. La lucha por los derechos humanos y las reivindicaciones democráticas ocuparon el centro de la escena y el PCR trabajaria estrechamente con sectores del peronismo bonaerense, mediante "alianzas tácticas" por el desarrollo de ese programa. ${ }^{12}$ Temporalmente, este vuelco a la actividad de masas coincidió con el desarrollo más sistemático de la acción gremial de sus distintos agrupamientos. ${ }^{13}$

Esta nueva orientación, el vuelco a un trabajo legal, que se sustentaba en un pronóstico de la imposibilidad de otra dictadura, provocó desacuerdos a nivel interno. Todavía en 1984 esto representó un punto sobre el que la dirección del partido tenía que pronunciarse:

Todavía hay compañeros que están por detrás de las masas en la comprensión del nuevo momento político y no despliegan su trabajo con audacia o mantienen posiciones "clandestinistas" por temor a que "pronto se dé otro golpe y en vez de 30.000 tengamos 300.000 detenidos-desaparecidos". No comprenden que la situación en 1984 tiene poca semejanza con la de 1975 [...]. Hoy es fundamental que las masas conozcan al partido y lógicamente a muchos de sus cuadros, para que el partido pueda crecer. Esto no significa que la organización del partido deje de ser clandestina y que lo que debe ser secreto se haga público y legal. (Partido Comunista Revolucionario, 2007: 336)

Las decisiones de la dirección del partido, que apuntaban a sacar a un sector de la militancia a la lucha legal y política, encontraban resistencia en la base de la organización. El trabajo politico en las fábricas se encauzó luego del comienzo de la normalización pactada entre el Estado y las viejas direcciones sindicales. El partido criticó a las direcciones que operaron una normalización desde arriba hacia abajo, desconociendo los

11. El partido salió a una actividad sistemática dirigida al conjunto de la población independientemente de los frentes sindicales donde se tenía inserción. En este sentido, la actividad se caracterizó por la distribución masiva de volantes que explicaban las caracterizaciones y las consignas. En este periodo, en consonancia con esta estrategia, se realizaron volanteos y agitaciones en lugares de tránsito como estaciones y actos públicos en la calle y en plazas.

12. El PCR participó de actividades en el GBA con sectores ligados a Herminio Iglesias. Ver Hoy, servir al pueblo, 19 de octubre de 1983.

13. Cuestión que puede observarse en las ediciones de su quincenario Hoy, servir al pueblo (1983-1984). 
procesos de organización que venían planteándose en distintos lugares con la retirada dictatorial a partir de 1982. La lucha por intervenir y dirigir estos procesos fue una prioridad en el partido: se planteó como una tarea inmediata la formación de listas para disputar la representación sindical. En este sentido, la alianza con el peronismo se reforzó frente al triunfo del radicalismo y su intento de reforma sindical. ${ }^{14}$

\section{Los enfrentamientos en el SMATA}

En este apartado, abordaremos sintéticamente las disputas entre los distintos agrupamientos al interior del gremio mecánico a partir de un análisis de las prácticas sindicales en dos momentos para nosotros claves: la constitución de la comisión normalizadora y las elecciones generales del gremio.

El PCR, para incursionar en los lugares de trabajo en momentos represivos, usaba métodos de militancia clandestina. El seguimiento de contactos y la discusión en el ámbito privado son la regla de este tipo de construcción política y sindical. ${ }^{15}$ En consonancia con la experiencia del SMATA Córdoba, impulsa la creación de Agrupaciones llamadas $1^{\circ}$ de Mayo que, como agrupamiento amplio, no exigia una activa participación en la vida del partido, sino una línea común de acción sindical. La herramienta fundamental en esta actividad fue la edición del boletín El Mecánico. ${ }^{16}$ Su distribución era selectiva, "circulaba por un ámbito reducido, se pensaba muy bien a quién dárselo. [...] el boletín podía aparecer en un locker, una mochila, en el baño, después veíamos como reaccionaba el compañero y recién ahí, dependiendo de su reacción, le presentábamos la agrupación".${ }^{17}$ En la cotidianidad, cuando predominaba la estrategia clandestina, se impulsaban acciones que no expusieran a ningún militante. ${ }^{18}$

La Lista Verde, durante la dictadura, desarrollaba su actividad con

14. PTP, "Las elecciones del 30 de octubre y el nuevo gobierno", 20 de noviembre de 1983; "La clase obrera se moviliza", Hoy, servir al pueblo, 15 de febrero de 1984, p. 12.

15. En el contexto represivo se visitaba a estos contactos en sus domicilios. La tarea de los militantes consistía en concurrir a las casas para "tomar mate y discutir política”. Entrevista a Miguel, dirigente del PCR (2016).

16. Su elaboración estaba a cargo de los elementos más activos de la agrupación y el partido, quien lo financiaba. Cada boletín respondía a las posiciones de la agrupación en determinada fábrica.

17. Entrevista a Miguel, dirigente del PCR (2016).

18. Entre ellas podemos destacar una misa en la localidad de Tigre en 1981 contra los despidos en SMATA, donde se hicieron presentes dirigentes del gremio, y una serie de acciones denominadas "pan y sopa". Esta última consistía en organizarse para consumir en el comedor de la fábrica solo los alimentos gratuitos (el pan y la 
normalidad sólo donde la patronal lo permitía. Ella negociaba con las empresas la posibilidad de establecer un "trabajo gremial" de tipo legal al interior de los lugares de trabajo, ${ }^{19}$ sin cuestionar los ritmos de producción, y con reclamos como la devolución de los fondos confiscados y las sedes gremiales (SMATA, 1985). Las energias, desde estos grupos, se articulaban entre el trabajo burocrático de reconstrucción de padrones, las redes de asistencia (fundamentalmente legal) y todo lo relacionado con el aparato gremial. Las direcciones gremiales peronistas tenian la posibilidad y la intención de negociar, no sin presionar, con el poder estatal la devolución de sus organizaciones. En cambio, el PCR y sus activistas hacian principal hincapié en sus denuncias en los ritmos de producción, cuestión que los llevaba a una confrontación directa con la patronal. ${ }^{20}$

Estos procedimientos guardaban una estrecha relación con la actitud tomada frente a los conflictos que surgian desde las bases en los últimos dos años de la dictadura. A partir del abordaje realizado hasta ahora sobre las experiencias de luchas que tienen lugar en Di Loreto, Mercedes Benz (Harari, Casco y Guevara, 2014) y Volkswagen (Molinaro, 2015, 2016), entre 1982 y 1983, podemos derivar una serie de conclusiones. Por un lado, las agrupaciones peronistas, que incluso componian las comisiones internas o núcleo de activistas de estas fábricas, se ocuparon fundamentalmente de utilizar los conflictos como herramientas de presión frente al Estado y las patronales en pos de su principal objetivo: la devolución de los fondos y reconstrucción del aparato gremial. A su vez, al presentarse como la opción más moderada de sindicalismo, frente a las expresiones de izquierda, los agrupamientos peronistas apelaban a colocarse como el único sector capaz de dirigir y satisfacer demandas sin la necesidad de confrontar impugnando la autoridad patronal, ni impulsar la movilización de bases. El poder de maniobra les permitió, en estos casos, llegar a un arreglo que incluía la expulsión de activistas antiburocráticos y una victoria parcial, presentada como la única posible. La manifestación concreta es que, por su accionar en estos conflictos, el sector de J. Rodríguez resultó beneficiado en el reparto de cargos de la comisión transitoria. Por otro lado, la izquierda que intervino en ellos, aunque su presencia era menor en número, tenía la línea de impulsar los conflictos hasta el final, evitando concesiones y victorias parciales.

sopa), una medida de protesta contra los aumentos de los precios (Agrupaciones Clasistas $1^{\circ}$ de Mayo, 1986).

19. Entrevista a Juan, directivo del SMATA (2016).

20. La agrupación del PCR denunciaba, a través de su boletín, que "las líneas que en las peores épocas marchaban a 7,8 o 9 pies por minuto, como máximo, hoy corren a 13 pies como mínimo". Ver El Mecánico, n 4, mayo de 1980. 
En este contexto, la posición de la Lista Verde abortó toda crítica y dicha comisión fue considerada un avance en la recuperación de los sindicatos. Además, se planteó que la Comisión fue "oportunamente" designada por el Ministerio de Trabajo de la Nación (SMATA, 1985) y que su composición constituía una distribución "equitativa" de los cargos. ${ }^{21}$ De esta manera, se dejó de lado toda crítica a la intervención militar. De forma contraria, el PCR denunció que la comisión normalizadora del SMATA "está elegida a espaldas de los verdaderos dueños del gremio, los 90.000 mecánicos", ${ }^{22}$ sentando una posición clara en relación a la normalización que se quería llevar a cabo.

El PCR cuestionó, de esta manera, la incidencia del gobierno militar en la elección de los delegados normalizadores, por medio del Ministerio de Trabajo. La Agrupación $1^{\circ}$ de Mayo, en enero de 1984, criticó a "Cardozo, Muñoz y Campeloni" (de la Lista Azul y Blanca) por formar parte de la Comisión "normalizadora" y ser "colaboracionistas" de los militares, pero no nombró al sector de Rodríguez. ${ }^{23}$ La política de defensa del gremio por parte del PCR fue criticada por otros sectores de izquierda: "el PCR tenía la política de que haya elecciones pero que las hiciera la Verde". ${ }^{24}$

Sin embargo, entrado ya 1984 el PCR se decidió a conformar la Lista Naranja, liderada por Miguel A. Delfini, ${ }^{25} \mathrm{y}$ formada, además, por militantes del MAS y del PO, ${ }^{26}$ con el objetivo de disputar las elecciones gremiales a nivel nacional, a pesar de tener un peso sindical fuerte sólo en Ford. La decisión de lanzamiento de la lista chocaba con la "alianza con el peronismo en la base" que el partido desarrollaba por aquel entonces. Inicialmente el PCR buscó una alianza con la Azul y Blanca. Al no poder concretarla decidió formar un frente con la izquierda que tenia inserción en el gremio.

21. Entrevista a Juan, directivo del SMATA (2016).

22. El Mecánico, n 8, junio de 1983, p. 2.

23. El Mecánico, $\mathrm{n}^{\circ} 10$, enero de 1984.

24. Entrevista a José, militante del MAS (2015).

25. Obrero de la sección Montaje de la empresa Ford (Pacheco), militante orgánico del PCR.

26. El armado de la lista tuvo foco en la planta de Ford de Gral. Pacheco. En el interior del país la Naranja tuvo base en Córdoba, pero su estructura era débil fuera de Buenos Aires. El PO y el MAS llamaron sin éxito a los comunistas a sumarse a la Lista Naranja: estos terminaron apoyando a José Rodríguez. Ver "Roque Romero: con la Naranja renace el Salamanquismo en Córdoba", Hoy, servir al pueblo, 12 de septiembre de 1984, pp. 8-9; "Avanza la lista independiente: llamamos a los militantes del PC a sumarse al esfuerzo del clasismo", Prensa Obrera, 5 de julio de 1984, p. 5; "Apoyo comunista a Rodríguez en SMATA", Solidaridad Socialista, 11 de octubre de 1984 , p. 4. 
Una vez oficializada la Lista Naranja, la estrategia del PCR cambió y, a partir de ese momento, se criticó expresamente a José Rodríguez planteando que convirtió al sindicato en un aparato burocrático alejado de las bases y, entre otras cosas, que "traicionó la lucha de Ford de 1983, negociándonos por una Normalizadora formada en el despacho de Villaveirán". ${ }^{27}$ El PO y el MAS, desde principios de 1984, habian planteado, con matices, como línea general la formación de una lista antiburocrática con base en Ford contra Cardozo y Rodríguez. ${ }^{28}$

Los comicios de octubre de 1984 arrojaron números muy parejos entre las dos listas peronistas. En Ford, la lista ganadora fue la Azul y Blanca, que obtuvo el $52 \%$ de los votos contra el $40 \%$ de la Lista Naranja y el 7, 9\% de la Lista Verde. En cambio, a nivel nacional, la Verde cosechó el $50 \%$ de los sufragios, la Azul y Blanca el $43 \%$ y la Naranja el 7\% (Santella, 2008). En estos números se observa, claramente, el poder nacional de la Lista Verde pero su debilidad en la empresa Ford, donde los otros dos agrupamientos tienen el apoyo de la mayoría de los obreros. Por otro lado, se refleja la victoria de la Azul y Blanca en Ford por sobre la Naranja en su intento de ser la oposición a José Rodríguez. La militancia clandestina, la falta de recursos y la tardanza en salir a hacer campaña (en parte producto de las prácticas que venian desarrollándose hasta el momento) consideramos que fueron un factor negativo en el desempeño electoral de la izquierda.

Por otra parte, la posición de la Lista Verde ante las elecciones estribó en el apoyo de infraestructura brindado por el gobierno de Alfonsin. ${ }^{29}$ Las consignas de la Verde en ese momento tenían que ver con reivindicaciones económicas y antidictatoriales: "Que no vuelva a suceder: intervención militar y represión en los sindicatos; salarios de hambre y cierres de empresas". ${ }^{30}$

27. Héctor F. Villaveirán fue Ministro de Trabajo y Seguridad Social entre el 2 de julio de 1982 y el 9 de diciembre de 1983. Ver El Mecánico, n 15, julio de 1984.

28. Ambos partidos caracterizaron las elecciones de delegados y las asambleas por reivindicaciones que se venían produciendo en distintas fábricas del gremio por fuera de las dirigencias sindicales como derrotas de la burocracia. En este sentido, conformar las listas antiburocráticas era, para ellos, profundizar una tendencia creciente de la movilización de las bases. Ver "SMATA: Por una lista única de la oposición antiburocrática", Prensa Obrera, 15 de marzo de 1984, pp. 8-9; "Elecciones sindicales. Formemos ya las listas de los nuevos dirigentes", Solidaridad Socialista, 31 de mayo de 1984, p. 3.

29. En relación con ello, un militante de la Lista Verde de la época afirmó: "La relación con el gobierno al principio fue buena, gracias a que, a través del ministro de trabajo, Juan Manuel Cassella, se pudo garantizar elecciones transparentes en el gremio" (entrevista a Juan, Directivo del SMATA, 2016).

30. Avance del Movimiento de Unidad Automotriz - Lista Verde, 1984. 
Las listas peronistas desconocieron a la izquierda en todo momento. La polarización que instalaron dio resultado y terminó beneficiándolos. Sin embargo, el enfrentamiento interburocrático entre Cardozo y Rodríguez se volvió muy agudo luego de las elecciones. La Azul y Blanca denunció fraude en la justicia, realizó huelgas, movilizaciones y medidas de fuerza reclamando al gobierno la impugnación de los comicios. La Lista Naranja, al no haber acuerdo entre los partidos que la integraban respecto de la posición a tomar frente a la denuncia de fraude de Cardozo, se fragmentó después de las elecciones. El distanciamiento se da sobre todo entre el MAS, que exige no dar ningún apoyo a Cardozo en su reclamo, y el PCR, que denuncia fraude y ataca al sector de Rodríguez. ${ }^{31}$ Esto llevó a que las corrientes pasen a actuar individualmente en la actividad cotidiana. El enfrentamiento entre los sectores peronistas, que se prolongó hasta marzo de 1985, coronó a Rodríguez al frente del gremio, quien logró cooptar progresivamente o inmovilizar a las seccionales opositoras, ${ }^{32}$ y debilitar momentáneamente a la izquierda.

\section{La experiencia en Ford Motors Pacheco}

En Ford, la represión tuvo su epicentro en el interior de la planta: el ejército se instaló en ella luego del paro mecánico de septiembre de 1976 y no se iría hasta abril de 1982. Sin embargo, esto no bastó para el desbaratamiento total de la organización dentro de la fábrica. En el periodo 1976-1983 se dieron acciones de resistencia como el sabotaje, el trabajo a desgano y la negativa a realizar horas extras (Lascano Warnes, 2012). El principal cambio dado en Ford durante la dictadura fue el despido masivo de determinados sectores de trabajadores, que excedió, por lejos, al grupo activista e implicó una reestructuración interna de la producción. Mientras a mediados de la década del 70 se registraban aproximadamente 7.500 obreros repartidos en 4 turnos (Lobbe, 2006), a comienzos de 1984 los trabajadores de planta eran entre 4.500 y 5.000 .

En el transcurso de la dictadura se produjo un gran recambio al interior de la planta. Luego de los despidos masivos ingresaron por tandas un número considerable de nuevos trabajadores. Entre ellos ingresó, en 1978, Miguel Ángel Delfini quien jugará un rol destacado en la organización interna de la fábrica (Agrupaciones Clasistas $1^{\circ} \mathrm{de}$

31. Ver "Se fracturó la Naranja del SMATA", Solidaridad Socialista, 25 de octubre de 1984, p. 12.

32. Ver "SMATA, un polvorín", Crónica, 16 de octubre de 1984, p. 10; "SMATA: impugnaciones y denuncias en comicios", Crónica, 10 de noviembre de 1984, p. 8; "SMATA en pie de guerra", Crónica, 3 de diciembre de 1984, p. 9; Avance del Movimiento de Unidad Automotriz - Lista Verde, enero de 1985. 
Mayo, 1986). No es casualidad, entonces, que sea en 1980 cuando comenzaron a aparecer los boletines de la recién conformada Agrupación Salamanquista en Ford. ${ }^{33}$

Según se denuncia en los volantes de la agrupación, entre 1976 y 1983 los despidos fueron una constante..$^{34}$ Estos dañaron a los propios activistas, que sólo huían del despido transformándose en disciplinados trabajadores. La dirección del partido de la Zona Norte del GBA tomó como una prioridad el desarrollo de su actividad en esta planta automotriz. Diseñó un tipo de trabajo donde se apuntaba a colocar gente de la agrupación y el partido en cada una de las secciones de la fábrica. ${ }^{35} \mathrm{El}$ trabajo fue predominantemente clandestino y buscó reclutar militantes mediante el volanteo esporádico ${ }^{36}$ y la distribución selectiva del boletín que editaban. En un balance posterior se da cuenta de ello:

Debíamos ir entramando una fuerza sin asomar la cabeza. Se decidió conformar la Agrupación Salamanquista, sección por sección, cuyos miembros no se identificaran y que se apoyase en la masa. El objetivo era acumular fuerzas en la lucha política y económica para -en determinado momento de la situación política-reorganizar y dirigir el cuerpo de delegados. [...] Vimos el boletín como un instrumento para desarrollar la corriente [...] Su circulación era reducida. Antes de dárselo a un obrero se lo acercábamos indirectamente [...], recién después le presentábamos la agrupación. (Segovia y Sánchez, 1984: 15)

Es decir, se estructura un plan de trabajo a largo plazo, sin confrontar directamente con sus adversarios y acercándose a los obreros peronistas, radicales o independientes más activos para incorporarlos a sus filas. La idea fundamental era esperar a que se produjeran hechos puntuales en los que se pudiera desempeñar una acción cuidadosa que pasara

33. Ver El Mecánico, n 1 , mayo de 1980.

34. Dicha situación puede constatarse en los volantes firmados por el agrupamiento del PCR en el período: "Mecánicos: prepararse para el paro general", 29 de marzo de 1979; "Ford: en defensa de la fuente de trabajo para todos", 29 de marzo de 1982; "Alerta en Ford", 8 de agosto de 1983.

35. En este período la fábrica estaba estructurada en 4 plantas: montaje (10 secciones), camiones (8 secciones), estampado ( 11 secciones) y motores (10 secciones). Ver Telegrama de resultados de elecciones de Cuerpo de Delegados, Cuerpo de delegados de Ford Motors Pacheco, 1 de febrero de 1984.

36. Aún bajo el gobierno militar se volanteaba durante la madrugada en las paradas de los micros que recogian a los trabajadores por el centro de los distritos más importantes de la zona (San Miguel, Escobar, Pilar, entre otros). La puerta de fábrica era considerada un lugar muy peligroso. Entrevista a Miguel, dirigente del PCR (2016). 
desapercibida. Durante la dictadura se defendió al gremio e incluso a José Rodríguez. Los activistas ligados al PCR reclamaban que el gremio se pusiera "a la cabeza" de los reclamos, como única instancia en la que ellos podian intervenir con un resguardo legal.

A comienzos de 1983, en Ford, hubo intentos de estructurar una comisión normalizadora. Un sector de la agrupación Lealtad a Kloosterman impulsó la propuesta, apoyándose en la patronal. Este intento no prosperó porque se sucedieron asambleas donde la cuestión salarial emergió como la principal preocupación de los trabajadores. Las masivas asambleas de fines de abril consiguieron imponer a la patronal el congelamiento de los precios del comedor, el ingreso de los miembros del sindicato a la planta y una futura elección de delegados por sección. El 29 de abril una nueva asamblea resolvió dejar en manos de la delegación del SMATA de zona norte la negociación de este último punto y el aumento salarial, con la condición de que se convocaria a una asamblea general en puerta de fábrica cuando hubiera novedades. Frente a esto, la agrupación del PCR señaló que, para que los intereses de los trabajadores no sean traicionados por el gremio y la patronal, la practica asamblearia debía ser sostenida. ${ }^{37}$

En agosto, finalmente, el aumento salarial se conquistó, aunque en menor medida de lo reclamado inicialmente. La comisión normalizadora del gremio se hizo presente en la planta y notificó que se había acordado con la patronal la normalización de la representación gremial al interior de la fábrica. Este proceso iba a tener lugar recién en un plazo de noventa días. La agrupación salamanquista se pronunció, bajo el argumento de que los mecánicos tenían problemas en ese momento, por la elección inmediata del cuerpo de delegados. Pese al descontento de algunos sectores de activistas, la asamblea aceptó la propuesta de los representantes del sindicato. ${ }^{38}$ Habria que esperar hasta enero de 1984 para que este proceso trunco, la reconstrucción de la organización sindical de base, vuelva a plantearse. La elección presidencial contribuyó al impasse. La agrupación del PCR, pese a que su partido apoyaba al peronismo, no realizó la campaña electoral en la fábrica.

Finalmente, la normalización propuesta no se produjo: fue posponiéndose y la patronal empezó a discutir la cantidad de delegados que podian elegirse por sector. Frente a esta situación, los activistas impulsaron asambleas en puerta de fábrica para resolver qué hacer ante el intento de la dirección normalizadora del gremio de votar una comisión

37. "Viva nuestra justa lucha", Agrupación Salamanquista $1^{\circ}$ de Mayo de Ford, 2 de mayo de 1983.

38. "Alerta en Ford", Agrupación Salamanquista $1^{\circ}$ de Mayo de Ford, 8 de agosto de 1983. 
provisoria que reconstruyera la organización de base según los parámetros acordados con la patronal. En ellas se rechazó la propuesta de la patronal y del ministerio de elegir un delegado cada 200 trabajadores. Las asambleas resolvieron elegir uno cada 50 y diagramaron un calendario para imponer su elección. ${ }^{39}$

Frente a estos acontecimientos, el PCR cambió de orientación y decidió que "había llegado el momento de desplegar nuestras fuerzas ante un estallido de masas" (Segovia y Sánchez, 1984: 20). Las elecciones para definir el cuerpo de delegados contaron con la oposición directa del ministro de Trabajo y la Comisión Transitoria. El Ministro, utilizando la ley 22.105, buscó desautorizar la elección de delegados. En este contexto, el 19 de enero se produjo una asamblea y toma de la fábrica por un pedido de aumento de salarios (surgió en la planta de camiones y se extendió a las demás). Ese mismo día se eligió, en las asambleas por plantas y general, "una dirección provisoria (la Comisión de los 21) [...]. Esta tenía como objetivo inmediato la lucha por el aumento salarial, y garantizar la elección del Cuerpo de Delegados por sección" (Agrupaciones Clasistas $1^{\circ}$ de Mayo, 1986: 58). La patronal reconoció la legitimidad de la Comisión y la elección de delegados, pero se negó a otorgar el aumento del $100 \%$ solicitado por las asambleas. Ante esto, se implementaron paros de dos horas por turno.

El 27 de enero se desarrolló otra asamblea y se decidió priorizar la elección del cuerpo de delegados por sobre la lucha salarial. El 30 y 31 se efectuaron las elecciones en la que fueron elegidos, entre 400 postulados, 84 delegados y 83 subdelegados, en su mayoría activistas ligados a este proceso, de la izquierda partidaria, independientes y sectores del peronismo. A su vez, en este preciso momento, la agrupación y el partido evaluaron que era hora de salir con todas las fuerzas que se habian acumulado en el trabajo clandestino para cumplir un rol de organizadores de carácter público, fundamentalmente porque la masa de los trabajadores se encontraba en movimiento (Segovia y Sánchez, 1984).

En este proceso quedó al descubierto que las posiciones eran hegemonizadas por la agrupación del PCR. Ésta expresaba, a través de su órgano, El Mecánico ( $\mathrm{n}^{\circ} 11$, marzo de 1984), la línea adoptada por las asambleas como propia: priorizar la lucha por la normalización para pelear en mejores condiciones de salario. En consecuencia, se optó por una politica de lucha larga respecto de los salarios y se prosiguió con los paros de dos horas por turno. Este plan de lucha, que se extendió por 50 días e incluyó una movilización a Plaza de Mayo (con el objetivo

39. Ver "Los obreros de Ford quieren delegados", Solidaridad Socialista, 19 de enero de 1984, p. 6; "Ford nuevamente en pie", Prensa Obrera, 28 de enero de 1984, p. 7; Segovia y Sánchez (1984: 20) 
de visibilizar el conflicto), se cerró el 6 marzo con un aumento salarial que se acercaba a lo reclamado por la Comisión Interna y posicionaba a los obreros de Ford como los mejores pagos de las terminales automotrices del país. ${ }^{40}$

La agrupación, en el balance de esta lucha, decía:

La decisión tomada de ir a una lucha larga fue justa, teniendo en cuenta que enfrentábamos un monopolio como Ford, con un gobierno que no reconocía a nuestro Cuerpo de Delegados, lo que de hecho le daba las ventajas a la patronal, $\mathrm{y}$ con dirigentes sindicales de SMATA que de palabra daban su apoyo y en los hechos retaceaban llamar a un paro nacional en solidaridad. (Agrupaciones Clasistas $1^{\circ}$ de Mayo, 1986: 62)

De esta forma terminó de consolidarse la organización fabril como un proceso de lucha concluido en una victoria. La agrupación del PCR elaboraba una línea clara para actuar, los demás partidos realizaban crónicas de lo sucedido, dando gran importancia al potencial antiburocrático de la organización de base naciente.

A partir de marzo de 1984, Ford participó de los paros nacionales de forma activa y con sus propias reivindicaciones. Durante 1984, hasta marzo de 1985, Jorge Castro jugó un rol importante en la organización interna de la fábrica, lo que explica el buen desempeño de la Azul y Blanca. En las prensas de los partidos que intervienen puede notarse, a partir de la ausencia, que en este periodo se produjo una parálisis en la comisión interna ante la realización de las elecciones y la división dentro del cuerpo de delegados que el armado de listas implicó. Luego de la definitiva victoria de Rodríguez a nivel nacional la situación organizativa volvió a plantearse dentro de la fábrica de General Pacheco. La patronal avanzó con retiros voluntarios y desmanteló la comisión interna, indemnizando a 38 de los delegados. ${ }^{41}$ Se impuso, entonces, la reconstrucción de la comisión interna y el PCR volvió a cobrar protagonismo, ahora sí, confrontando directamente con la Lista Verde que hegemonizaba la dirección del gremio nacional. El período abierto es de

40. Ver "Ford: un primer round", Prensa Obrera, 15 de marzo de 1984, pp. 8-9; "Ford, el reclamo llego a la rosada", Solidaridad Socialista, 8 de marzo de 1984, p. 7; "Los obreros de Ford retoman el camino del SMATA-Córdoba", Hoy, servir al pueblo, 17 de marzo de 1984, páginas centrales; "El presente y el futuro del SMATA visto desde Ford”, Solidaridad Socialista, 5 de abril de 1984, p. 2.

41. Entre ellos se encontraba Jorge Castro, quien aceptó la indemnización y abandonó la militancia gremial. Ver "Ford: reconstruir el cuerpo de delegados para frenar los despidos", Prensa Obrera, 7 de marzo de 1985, p. 2; “¿Por qué izquierda y derecha apoyan la ocupación de Ford?”, Ámbito Financiero, 2 de julio de 1985, p. 44. 
ascenso de la organización, una muestra de ello es el acto realizado con motivo del $1^{\circ}$ de Mayo en puerta de fábrica que congrega entre $4.000 \mathrm{y}$ 5.000 trabajadores. ${ }^{42}$

Esta experiencia encontró su punto más alto en la toma de junio y julio de $1985,{ }^{43}$ que puso de manifiesto una organización rigurosa. Frente al despido de 33 trabajadores se respondió unánime e inmediatamente con el bloqueo de los portones y se votó la toma del establecimiento. ${ }^{44}$ La ocupación tuvo un fuerte impacto mediático y la campaña de demonización fue unánime desde la gran prensa, la burocracia sindical y el gobierno que confluyeron con la patronal en la tarea de derrotar la medida (Molinaro, 2013).

Para el PCR, a quien todas las voces reconocen en sus activistas la dirección del conflicto, la ocupación resultaba la única medida viable "frente a las mentiras del gobierno, la actitud artera de la patronal y la traición de los dirigentes del SMATA". ${ }^{45}$ Luego de producido el desalojo de la planta, que implicó el fin de la toma luego de 18 días, la lectura del partido no lo consideró como una derrota. La dirigencia del SMATA casi no hace mención del conflicto de Ford en su Balance de 1985 y, cuando se refiere a él, lo hace diciendo que fue un "fracaso que tuvo como responsable a una conducción gremial interna que facilitó motivos a la empresa para despedir a gran cantidad de obreros" (SMATA, 1986: 6). La lista Verde, de esta manera, ratificó la línea puesta en práctica en los conflictos de 1982-1983, con lo cual culpabilizó de los despidos a direcciones gremiales irresponsables, pudiendo pactar con la patronal el despido de todos los activistas comprometidos en el proceso, logrando ingresar a la planta y, sobre la base de una derrota, tomar la conducción de su organización interna.

La experiencia de Ford será la más resonante en el SMATA de la época y la última expresión de una oposición de la izquierda a las listas peronistas. El fin de la ocupación de Ford significó la clausura de un proceso que comenzó de la mano del sindicalismo de base de la planta. El PCR, sosteniendo un trabajo sistemático, supo insertarse en esta im-

42. Ver "Gran acto proletario en la puerta de Ford", Prensa Obrera, 9 de mayo de 1985, p. 8; "Un $1^{\circ}$ de Mayo memorable", en Agrupaciones Clasistas $1^{\circ}$ de Mayo (1986), p. 42.

43. Sobre estos acontecimientos existe una amplia bibliografia que el lector puede consultar (Hernández, 1985; García Allegrone, Partenio y Álvarez, 2003; Giniger, Guevara, Hernández y Rivero, 2010; Molinaro, 2013; Agrupaciones Clasistas $1^{\circ} \mathrm{de}$ Mayo, 1986).

44. Ésta fue la respuesta de los trabajadores frente a la violación de un acuerdo firmado en mayo del mismo año, que implicaba el cese de despidos por un semestre. Muchos actores han considerado la violación de este acta como una provocación premeditada por la patronal para precipitar el conflicto.

45. El Mecánico, n 17, julio de 1985. 
portante fábrica y dirigir a los trabajadores en los momentos más duros de la ofensiva patronal. Las herramientas puestas en juego para desarrollar sus objetivos fueron múltiples llegando incluso a tener gente en la sección administrativa de la planta que supo filtrar información sobre los números contables, ganancias y planes que manejaba la patronal. ${ }^{46}$

\section{Consideraciones finales}

En este trabajo hemos analizado la estrategia que el PCR desarrolló en el SMATA del retorno a la democracia. Nuestro estudio nos permitió indagar en el modo como el partido logró articular las demandas de los trabajadores e integrarlas en una dinámica que implicó el fortalecimiento de la agrupación que actuaba en la planta de Ford.

A partir del análisis de las fuentes consideradas y de los testimonios reunidos, pudimos observar que la decisión que asumió el partido de insertarse en la fábrica y dirigir su Comisión Interna tuvo resultados positivos, ya que la estrategia y métodos de militancia les fueron útiles a los activistas que se ocuparon de desarrollar esta tarea. Todo este proceso puso de manifiesto una conjunción entre acciones conscientemente desplegadas por los militantes y el estallido espontáneo del colectivo obrero. El PCR diseñó e implementó acciones que, como fuimos explicando, convergieron en diversos grados con los intereses de los trabajadores de la fábrica. Tal modalidad de acción determinó -a pesar de los altibajos, y de los encuentros y desencuentros entre sus miembros- la importancia que el agrupamiento logró adquirir. El punto más significativo que identificamos es el que corresponde al momento previo a la toma de 1985. En este sentido, los militantes del partido y la agrupación intentaron ligar su existencia práctica con la realización material de las aspiraciones de las bases y encontraron alli un canal de desarrollo. Sostenemos que este partido logró postularse como dirección de un proceso que había sido puesto en marcha por los trabajadores de la planta. Puntualizamos que, por no haber dependido exclusivamente de la agrupación y de su estrategia, no se trató de un proceso unilateral: al movilizarse, el conjunto de los trabajadores de Ford determinó el ritmo y la orientación de la experiencia. Sin embargo, destacamos que el partido, en tanto organización, desempeñó un rol importante al actuar

\footnotetext{
46. Un militante universitario del partido ingresa a la planta como administrativo por los años 80. Esto posibilitó al agrupamiento contar con información concreta sobre la situación de la producción y la rentabilidad de la empresa, ante una permanente alegación de crisis inminente. Esto les permitió, durante la toma de 1985, desmentir que la patronal se encuentre en planes de cerrar la planta de General Pacheco. Entrevista a Miguel, dirigente del PCR (2016).
} 
como un agente de transmisión de formas de lucha y organización que se encontraban presentes en la historia de los trabajadores del sector.

Asimismo, hemos registrado que la experiencia no estuvo exenta de contradicciones, entre las cuales podemos señalar la conflictiva relación que el partido y sus organizaciones obreras tenian con el peronismo. Por su programa, el PCR no intentó separarse tajantemente de aquel y ello tuvo su correlato en las organizaciones de base. Tal solapamiento se manifestó, según pudimos observar, en dos momentos puntuales. El primero de ellos correspondió a la situación en la que, con cierta autonomía, la agrupación de Ford no hizo campaña por el peronismo en las elecciones nacionales de 1983, en contra de la política del partido. El segundo de ellos tuvo lugar durante las elecciones nacionales del gremio en 1984, con la pérdida de iniciativa y protagonismo durante el enfrentamiento interburocrático.

Consideramos que este trabajo avanza en el abordaje de la relación que, en un determinado período histórico, puede plantearse entre base y vanguardia. Como planteamos en el inicio de nuestra indagación, la noción de vanguardia obrera brinda una clave de acceso a la comprensión de parte del accionar del partido. Si bien nuestra aserción ameritaría un estudio más profundo a los fines de ampliar el campo de estudio a la participación del partido en otros escenarios análogos al que hemos estudiado, podríamos aventurar que el PCR actuó como una vanguardia en el movimiento obrero de la época.

Creemos que conocer el recorrido, la formación y los antecedentes de la organización obrera en Ford y el accionar de las organizaciones que participaron en ella nos permitirá pensar, con nuevas herramientas, los orígenes y el desenlace de la toma del establecimiento ocurrida en 1985. En este sentido, aunque colateralmente, creemos haber contribuido al debate sobre dicho acontecimiento. En relación con ello, arriesgamos que la derrota de la experiencia se debió, fundamentalmente, al aislamiento que sufrió Ford en un contexto en el que los métodos de lucha no tenían esa impronta en el conjunto del movimiento obrero organizado.

Por último, queremos destacar que la investigación realizada tiene una doble potencialidad: por un lado, ha dado lugar a las aseveraciones que hemos enunciado y, al mismo tiempo, nos ha señalado las vacancias de las que resta ocuparse para obtener una visión general del rol desempeñado por las organizaciones de base y la izquierda en este periodo.

\section{Bibliografia}

Abdala, Omar (2015), Rupturas y continuidades en las formas de acción y resistencia de los trabajadores. El caso Ford Motors Argentina (1970-1985), tesina de Licenciatura en Sociología, IDAES-UNSAM, 2015. 
Agrupaciones Clasistas $1^{\circ}$ de Mayo (1986), La ocupación de Ford. 18 dias que conmovieron la Argentina, Buenos Aires.

Asociación de Fábricas de Automotores (1986), Anuario 1986, Buenos Aires.

Basualdo, Victoria (2006), "Complicidad patronal-militar en la última dictadura argentina: Los casos de Acindar, Astarsa, Dálmine, Siderca, Ford, Ledesma y Mercedes Benz", en Engranajes, Federacion de Trabajadores de la Industria y Afines (FETIA), n 5, 2006.

Belardinelli, Pablo (1994), "El marco político de la conflictividad obrera", en Ernesto Villanueva (coord.), Conflicto obrero. Transición politica, conflictividad obrera y comportamiento sindical en la Argentina 1984-1989, Buenos Aires: Universidad Nacional de Quilmes, pp. 103-149.

Bitrán, R. y A. Schneider (1992), "Dinámica social y clase trabajadora durante la última dictadura militar de 1976-1983. Estudio de la zona norte del Gran Buenos Aires: Del Carlo y Ford Motors", en L. Rodríguez, M.C. D’Araujo, R. Bitrán, A. Schneider, J. Dowling y M. Gordillo, Nuevas tendencias en el sindicalismo argentino, Buenos Aires: Biblos-Simon Rodriguez.

García Allegrone, Verónica, Florencia Partenio y María Inés Fernández Álvarez (2003), "Ocupaciones fabriles: un rastro en las experiencias históricas", VI Congreso Nacional de Estudios del Trabajo: Los trabajadores y el trabajo en la crisis, Buenos Aires. Disponible en www.aset. org.ar/congresos/6/archivosPDF/grupoTematico03/006.pdf(consultado en agosto de 2016).

Giniger, Nuria, Sebastián Guevara, Marcelo Hernández y Cintia Rivero (2010), "Las huellas del terrorismo de estado sobre el movimiento obrero. Los casos de Ford y Acindar", en Claudia Figari, Paula Lenguita y Juan Montes Cató (comps.), El movimiento obrero en disputa. La organización colectiva de trabajadores, su lucha y resistencia en la Argentina del siglo XX, Buenos Aires: Ciccus, pp. 143-162.

Harari, Ianina, Mariano Casco y Sebastián Guevara (2014), “Conflictos obreros en la industria automotriz argentina entre 1973 y 1983: un análisis de la acción obrera en el lugar de trabajo antes y después del golpe militar", VII Seminario Internacional de Politicas de la Memoria, Buenos Aires: Centro Cultural Haraldo Conti.

Hernández, Víctor (1985), "La ocupación de fábrica como forma de lucha obrera. El caso de Ford Motors Argentina", Cuaderno CICSO, Serie Estudios $n^{\circ} 62$.

Lascano Warnes, Florencia (2012), Cambios y continuidades en la historia de los trabajadores industriales argentinos (1973-1983). Una aproximación a través del caso Ford Motor Argentina S.A., tesis de Maestría, Universidad Nacional de General Sarmiento.

Laufer, Rodolfo (2015a), "El clasismo en el SMATA Córdoba. La lista Marrón de 1972", XI Jornadas de Sociología Universidad de Buenos Aires.

- (2015b), "El clasismo en el SMATA Córdoba. Ocupaciones fabriles, de- 
mocracia sindical e izquierda clasista: la toma de la matricería Perdriel, mayo de 1970", en Estudios del Trabajo, vol. 49.

Lenin, Vladimir Ilich (2004), ¿Qué hacer? Problemas candentes de nuestro movimiento, Buenos Aires: Luxemburg.

Lissandrelo, Guido (2014), "La discusión estratégica en la izquierda argentina en los años 70. Aproximación al debate entre guerrillerismo e insurreccionalismo en el nacimiento del Partido Comunista Revolucionario (PCR), 1967-1972", Andes, Salta.

Lobbe, Héctor (2006), La guerrilla fabril. Clase obrera e izquierda en la Coordinadora de Zona Norte del Gran Buenos Aires (1975-1976), Buenos Aires: Ediciones RyR.

Mandel, E. (1972), La teoría leninista de la organización, Buenos Aires: Indo-Amer.

Molinaro, Leandro (2013), "La democracia del Nunca más y el movimiento obrero. La ocupación de la planta Ford de General Pacheco en 1985", en Archivos, año I, $\mathrm{n}^{\circ} 2$, pp. 55-75.

- (2015), "El movimiento obrero en el ocaso de la dictadura militar. Principales conflictos en el gremio automotriz (junio de 1982 a diciembre de 1983)", VI Jornadas de la División Historia y III Taller de Historia Regional, Luján, 22 y 23 de octubre de 2015.

- (2016), "El reposicionamiento de la burocracia sindical en el ocaso del "Proceso" (julio de 1982 a diciembre de 1983)", Archivos, año IV, n 8, pp. 33-53.

Partido Comunista Revolucionario (2007), Documentos aprobados por el PCR a partir de su $3^{\circ}$ Congreso, marzo de 1974 , hasta su $4^{\circ}$ Congreso, abril de 1984. Segunda parte 1980-1984, Tomo 4, Buenos Aires: Publicaciones $35^{\circ}$ aniversario del PCR.

Pozzi, Pablo y Alejandro Scheneider (1994), "Crisis y recomposición de la clase obrera argentina (1982-1992)", en Daniel Campione (comp.), La clase obrera de Alfonsin a Menem, Buenos Aires: CEAL, pp. 35-81.

Pozzi, Pablo (2008), Oposición obrera a la dictadura, 1976-1982, Buenos Aires: Imago Mundi.

Santella, Agustín (2008), Trabajadores, sindicato y conflictos en la industria automotriz. Un estudio de caso (1989-2006), tesis de doctorado, Buenos Aires: Universidad de Buenos Aires.

Segovia, Mario y Pedro Sánchez (1984), "Los obreros de Ford retoman el camino del SMATA cordobés", Política y Teoría, año II, n 5, pp. 10-26.

SMATA (1985), Memoria y Balance 1985, Buenos Aires.

- (1986), Memoria y Balance 1986, Buenos Aires.

Zorzoli, Luciana (2016), "La normativa sindical entre la dictadura y el alfonsinismo, propuesta de sistematización", en A. Schneider y P. Ghigliani (comps.), Clase obrera, sindicatos y Estado (1955-2010), Buenos Aires: Imago Mundi, pp. 149-172. 
Titulo: "Strategy and insertion of the Partido Comunista Revolucionario in the SMATA (1979-1985)”.

Resumen: El artículo aborda la estrategia del Partido Comunista Revolucionario y su inserción en el Sindicato de Mecánicos y Afines del Transporte Automotor (SMATA) durante el proceso de normalización sindical (1979-1985). Nuestro interés reside en comprender el modo en que este partido de izquierda logró insertarse en un colectivo de trabajadores y dirigir una parte de ellos. Analizamos las estrategias y luchas que nos ponen de manifiesto su grado de inserción y su capacidad de dirección frente al colectivo obrero. Para ello nos valdremos, fundamentalmente, de la experiencia llevada a cabo por esta organización en la planta de Ford Motors Pacheco.

Palabras clave: transición democrática - movimiento obrero - Partido Comunista Revolucionario - SMATA

Abstract: This paper approaches the Revolutionary Communist Party's strategy and its insertion in the Mechanics and Self-propelled Transport and Similar Trade Union (SMATA), through the union normalization process (1979-1985). Our interest lies in understanding the way in which this left wing party managed to insert in a collective of workers and lead a part of them. We analize the strategies and struggles that reveal its grade of insertion and its leading ability towards the labourer collective. In this way, we will essentially seize on the experience carried out by this organization in the Ford Motors Pacheco plant.

Keywords: democratic transition - labour movement - Revolutionary Communist Party - SMATA 